\title{
The Relationship of Father's Involvement in Parenting with the Independent Level of Children Daily Living Activity in Children with Mental Retardation in SLB-C TPA Jember Regency
}

\author{
Elsiana Dwi Cahya ${ }^{1}$, Latifa Aini Susumaningrum², Kholid Rosyidi Muhammad Nur ${ }^{3}$ \\ ${ }^{1}$ Faculty of Nursing, Universitas Jember, Indonesia \\ 2Faculty of Nursing, Universitas Jember, Indonesia; latifa as.psik@unej.ac.id (Corresponding Author) \\ ${ }^{3}$ Faculty of Nursing, Universitas Jember, Indonesia
}

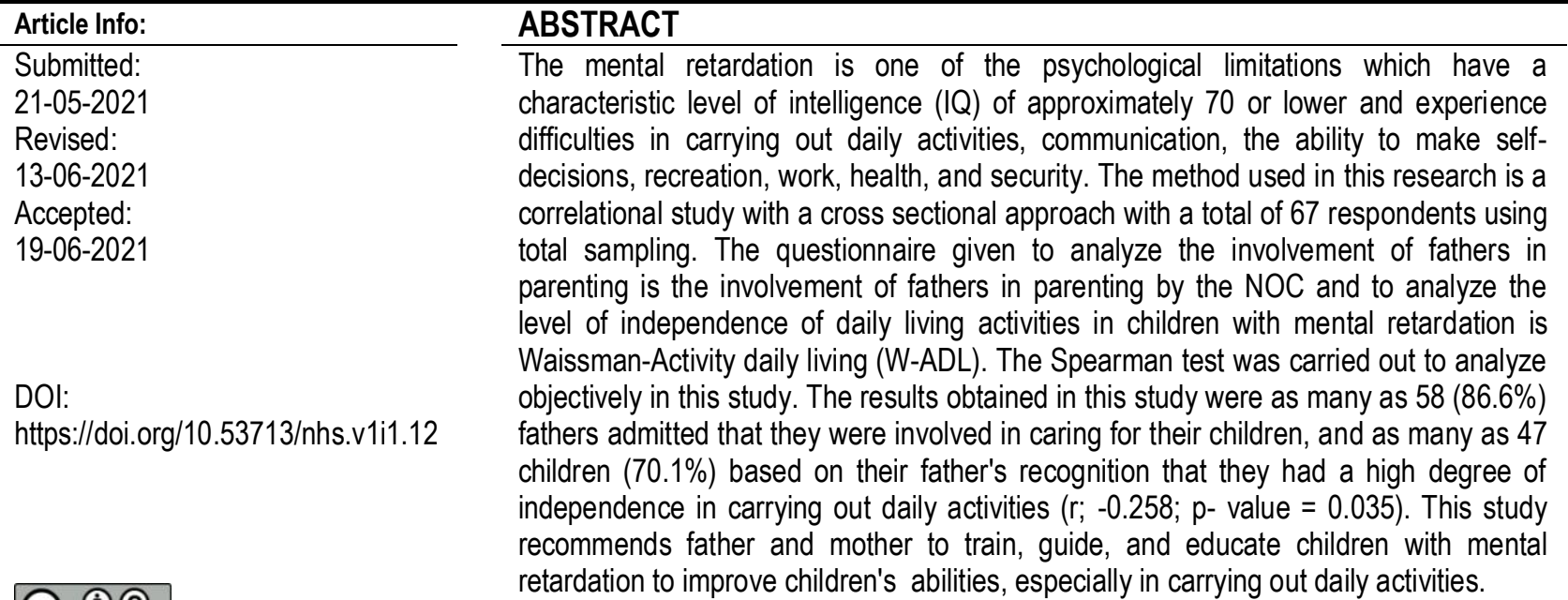

This work is licensed under CC BY-SA License.
Keywords: father involvement, independence activity daily living, children with mental retardation

\section{INTRODUCTION}

Mothers who give birth do not all give birth to their children in normal circumstances. Some of them have limitations both physically and psychologically (Pravitasari et al., 2002). Mental retardation is an example of psychological limitations that can be found in various places. Children with mental retardation have a characteristic intelligence level or intelligence quotient (IQ) of approximately 70 or lower and experience difficulties in communication, taking care of themselves, the ability to make their own decisions, recreation, work, health, and safety (Situmeang et al., 2016). Mental retardation has characteristics that according to the American Association Of Mental Retardation (AAMR) are divided into 4 , namely mild mental retardation with an $I Q$ of $50-70$, moderate retardation with an $I Q$ of $35-50$, severe mental retardation with an IQ of 20-35, and very severe mental retardation with an IQ. IQ is less than 20 . Based on Riskesdas (2018), it shows the proportion of disabilities at the age of $5-7$ is $3.3 \%$ and at the age of $18-59$ is $22 \%$. Mentally retarded children accommodated in SLB-C in East Java Province reached 6,633 people or $61.21 \%$ of all children with special needs in East Java in 2013/2014, consisting of 3,994 people with mild mental retardation or $36.86 \%$, moderate mental retardation 2,639 people or $24.35 \%$ and severe mental retardation 4.203 people or $38.79 \%$ (Ikawati et al., 2017)). According to the Central Statistics Agency of East Java Province in 2016, the number of disabilities was 30,522 people, while in Jember Regency there were 2590 people. According to Anggraini (2016) in (Alfianti, 2018) in Jember Regency, 46 children are suffering from mental retardation in SLB N Jember, and 59 children in SLB C TPA (Education and Care Park) Jalan Jawa and Bintoro(Hardiyanti, 2018). The level of independence of children with mental retardation in a study conducted by Abidin (2017), before being given a hand puppet game, as many as $25 \%$ of children received partial assistance, while $75 \%$ of children received full assistance in fulfilling daily living activities such as eating, drinking and cleaning themselves. After being given the hand puppet game, the level of independence of mentally retarded children as many as 10 out of 12 children was classified as independent, while mental retardation children who received partial and full assistance decreased to $8.3 \%$ respectively. Another study states 
that most of the mentally retarded children aged 10-14 years in SLB Negeri Part B Jayapura are already independent in self-care with a proportion of 21 children $(65.6 \%)$ most of whom can take care of themselves such as defecating and urination, bathing, dressing, combing hair and washing hands after and before eating (Rumaseb et al., 2018). According to Sari \& Santy (2016), in their research, it was explained that the level of personal hygiene for children with mental retardation increased due to family support, this is because the family is the closest person to the child where parents' habits can be imitated so that it affects children's information about personal hygiene. Based on the results of research, children with mental retardation who do not get support from their family have a 14 times chance of being independent (Syahda, 2018). This proves that the independence of children with mental retardation depends on their parents. Parents play an important role in educating, guiding, and directing children to become independent. The role of parents is considered important because they have physical and psychological closeness with children (Sartika, 2017). One form of role as parents that can be given to their children is to provide support in the form of attention and affection to help the child's growth and development. Family support is a process of relationship between family members with reciprocity, feedback, and emotional involvement (Zubaidah, 2014)

The role of parents is considered to be able to increase the level of independence in children. The role of parents who can increase the level of independence of children by involving children in daily activities, helping children in positive activities and providing rewards such as praise, not giving punishment, teaching socializing with the community and peer environment, and helping activities both at home and outside the home (Kleefman, 2014). According to Svensson in (Lestari, 2012) states that the involvement of parents in parenting can lead to closeness in a negative correlation between children and parents. Parenting which was originally synonymous with the responsibility and role of the mother is now also the responsibility of a father (Wangge, 2016) The involvement of fathers in parenting has begun to get attention and is associated with sharing aspects of children's lives. Currently, the role of fathers is not only focused on fulfilling economic needs, but also on family care, participation in controlling and directing children, to problems experienced by children. Haque \& Rahmasari (2013), stated in their research that the involvement of fathers in parenting can affect children's prosocial behavior by 0.621 or $62.1 \%$. Parents (fathers and mothers) who are involved in parenting can improve the development of autistic children by $80 \%$ (Dewi Yustika Tri et al., 2018). Research conducted on children with mental retardation accompanied by attention deficit hyperactivity disorder (ADHD) states that the harmony of father and mother in caring for children at home can develop children's potential (Astrella, 2018).

Based on this description, the researcher wanted to know how the father's involvement in parenting, especially in families with mentally retarded children. This is because the child's condition is one of the problems that can affect the survival of the family. Health workers, especially nurses, are expected to be able to provide appropriate interventions to increase the independence of children's daily living activities by involving fathers, this is done to get a good solution to the problem. This makes researchers interested in examining the relationship between the involvement of fathers in parenting and the level of independence of daily living activities on mental retardation.

\section{METHOD}

The research design used in this study is a correlational study with a cross-sectional approach using a sampling technique, namely total sampling. The population of this research is the father who has children with mental retardation in SLB-C TPA Jember, as many as 67 students with mental retardation. 


\section{RESULT}

\section{Characteristics of fathers and children}

Table 1. Characteristics of fathers and children (February 2020; $n=67$ )

\begin{tabular}{lc}
\hline \multicolumn{1}{c}{ Father and Son Characteristics } & $\mathrm{n}(\%)$ \\
\hline Father's age & $45(67.2 \%)$ \\
Early adulthood & $22(32.8 \%)$ \\
Middle adult & $25(37.3)$ \\
\hline Father's education & $17(25.4)$ \\
Elementary school & $19(28.4)$ \\
Junior High & $6(9.0)$ \\
High school & \\
College & $36(53.7)$ \\
\hline The gender of the child & $31(46.3)$ \\
Man & \\
Women & $39(58.2)$ \\
\hline Category of mental retardation & $28(41.8)$ \\
Mild &
\end{tabular}

Based on the results of the study, it is known that the age of the respondents was categorized into two categories, namely early adults as much as $45(67.2 \%)$ and middle adults as many as $22(32.8 \%)$. Elementary school (SD) is the most recent education of fathers (37.3\%). The results of this study also showed that as many as $36(53.7 \%)$ students had male gender. The mild category in children with mental retardation was the most (58.2\%).

\section{Father's Involvement in Parenting}

Table 2. Indicators and Categories of Father's Involvement in Parenting (February 2020; $N=67$ )

\begin{tabular}{lc}
\hline \multicolumn{1}{c}{ Indicator } & $\mathrm{n}(\%)$ \\
\hline $\begin{array}{l}\text { Boiology } \\
\text { Mn (SD) }\end{array}$ & $24.42(7.13)$ \\
Social & \\
$\quad$ Md (P25-P75) & $46(39-51)$ \\
$\begin{array}{l}\text { Psychology } \\
\text { Mn (SD) }\end{array}$ & \\
$\begin{array}{l}\text { Spiritual } \\
\text { Md (P25-P75) }\end{array}$ & $25.63(7.39)$ \\
\hline $\begin{array}{l}\text { Father Involvement Category } \\
\text { Low }\end{array}$ & $5(4-5)$ \\
$\quad$ Moderate & $5(7.5)$ \\
High & $4(6)$ \\
\hline
\end{tabular}

Based on table 2., each indicator of a father's involvement in parenting has a value including, the mean value of social indicators which is higher than spiritual indicators of 46 , while the average of psychological indicators is 25.63 higher than biological indicators. This shows that the involvement of fathers in parenting is mostly done in the social and psychological fields of children. Middle and high mean values illustrate the behaviors that fathers frequently engage in parenting. and at the high level of involvement of fathers in parenting, there were 58 fathers involved in caring for children with mental retardation in SLB-C TPA Jember. 


\section{The Level of Independence of Daily Living Activity in Children with Mental Retardation}

Table 3. Indicators and Categories of the Level of Independence of Daily Living Activity in Children with Mental Retardation (February 2020; $\mathrm{N}=67$ )

\begin{tabular}{lc}
\hline \multicolumn{1}{c}{ Indicator } & $\mathrm{n}(\%)$ \\
\hline $\begin{array}{l}\text { Toileting } \\
\text { Mn (SD) }\end{array}$ & $1.55(0.5)$ \\
\hline $\begin{array}{l}\text { Clean yourself up } \\
\text { Md p25-p75 }\end{array}$ & $4(2-4)$ \\
\hline $\begin{array}{l}\text { Get dressed } \\
\text { Mn (SD) }\end{array}$ & $1.58(0.49)$ \\
\hline $\begin{array}{l}\text { Eat and drink } \\
\text { Md P25-P75 }\end{array}$ & $8(5-9)$ \\
\hline $\begin{array}{l}\text { Switch places } \\
\text { Mn (SD) }\end{array}$ & $4.48(1.35)$ \\
\hline $\begin{array}{l}\text { Independent Level Category Activity Daily Living } \\
\text { It depends } \\
\text { Independent }\end{array}$ & $30(44.8)$ \\
\hline
\end{tabular}

Based on table 3., shows that the level of independence of daily living activities in children with mental retardation on the indicator of moving places has an average of 4.48 higher than the indicators of toileting and dressing. The median value on the indicator of moving places gets a high score of 8 then the indicator of eating and drinking Middle and high mean values indicate the most frequently performed daily activities. This shows that children with mental retardation in SLB-C TPA Jember are more independent in carrying out daily activities such as eating and drinking and moving places. The results of the study based on table 3 . also show that the level of independence of daily living activities in the medium category is $30(44.8 \%)$ and the high category is $37(55.2 \%)$.

\section{The Relationship between Father's Involvement in Parenting and Independent Level of Children's Daily Living Activity with Mental Retardation in SLB-C TPA Jember.}

Table 4. The Relationship between Father's Involvement in Parenting and Independent Level of Children's Daily Living Activity with Mental Retardation in SLB-C TPA Jember (February 2020; $n=67$ )

\begin{tabular}{ccc}
\hline Variable & \multicolumn{2}{c}{ Activity daily living in children with mental } \\
Involvement of fathers in parenting & \multicolumn{2}{c}{ retardation } \\
& $r$ & -0.258 \\
& p-value & 0.035 \\
\hline
\end{tabular}

Based on table 4., the correlation results obtained with a p-value of 0.035 (alpha <equal to 0.05 ) which means that $\mathrm{Ha}$ failed to be rejected, thus the involvement of the father in parenting with the level of independence of the daily living activity of children with mental retardation in SLB-C TPA Jember has a relationship.

\section{DISCUSSION}

The results of this study indicate that $58(86.6 \%)$ fathers are involved in caring for their children who are categorized as high in mental retardation. This research is supported by previous research by Rismhandani (2018), which states that as many as $51.6 \%$ of fathers involved in parenting are in the high category. Nikmatunasikah (2018), said that fathers who are involved in parenting can improve psychomotor development, cognitive, affective, social skills, and children's education, especially children with mental retardation. Rohmalina et al., (2019), said that the high and low involvement of fathers in parenting can have an impact on the difficulty of regulating children's emotions so that children will avoid when fathers begin to be involved in parenting. So that the involvement of fathers in high parenting can be beneficial for the emotional control and behavior of children, especially children with mental retardation.

The results of this study indicate that the indicators often used by fathers in caring for their children are related to social indicators and psychosocial indicators. Social indicators show the results of $61(91 \%)$ fathers doing things such as stimulating social and moral development, increasing the values of social functions, providing supervision, interacting 
according to the child's temperament, disciplining children according to age and using open communication. This is by the theory developed by Asy \& Ariyanto (2019), which is known as the paternal CRITISM (communication, responsibility, interaction, teaching, social competence, and monitoring). Communication that is similar to a father can do in the form of verbal such as speaking, listening, criticizing, and giving praise to children and so on, while non-verbal ones are in the form of touching, giving affection, shaking hands, expressing faces, waving, and so on. In addition, fathers have a responsibility to provide protection. Fathers are also expected to be able to interact with children indirectly but easily accessed by children and directly such as accompanying and monitoring children who are playing or learning so that they can positively improve the emotional side of the child and father. Fathers can instill a disciplined, moral, responsible attitude and have a healthy lifestyle towards their children. Children's social skills such as making friends with their peers, going to places of worship, watching with friends, attending birthday parties, and mourning are the duties of the father to develop them. Father monitoring also needs to be done to children in carrying out daily activities, children's health, and children's social life. Increasing the social aspects of children can make the relationship between father and child warmer and more harmonious. In addition, children can have long friendships and can adapt to the school environment, both individually and in groups of good quality and are positive.

Psychosocial indicators in this study showed that as many as $60(89.5 \%)$ fathers did things such as stimulating emotional development, empathy in children, showing loving relationships, being realistic about the expectations of the parents 'roles, expressing satisfaction from the parents' roles, and express self-esteem. Khoiriyyah (2020), states that building feelings of empathy (respecting feelings) is a way to increase the understanding of parents, especially fathers to understand what the child is feeling, what the child needs, so that parents, especially fathers, can meet the child's needs. This research is supported by research from Kosasih (2018), which states that $26 \%$ of respondents (parents) accept rates of children with moderate and high mental retardation. Child care can be successful if the family accepts and manages the child's condition, meets the child's growth and development needs, and develops aspects of children's social support (Supartini, 2004).

Based on the results of the Spearman test which shows that there is a relationship between the involvement of the father in parenting with the level of independence of daily living activities in children with mental retardation in SLB-C TPA Jember with a $p$-value of 0.035 . This shows that the involvement of the father in parenting is directly proportional to the level of independence of daily living activities in children with mental retardation. due to the form of support and motivation from the father. The higher the involvement of the father in parenting, the higher the level of independence of daily living activities in children with mental retardation, and vice versa. Fathers can help children in carrying out daily activities that begin by giving examples first, then the children are still accompanied by the father so that the child will get used to it and become independent. According to Supartini (2004), one of the important things related to child care is the involvement of the father in the care of the child or the husband to take care of the child.

Respondents in this study said that what fathers do in parenting is getting involved in child toileting, cleaning themselves, dressing, and moving places, while eating and drinking is usually done by the mother and occasionally the father helps. Some fathers said they were not involved in helping their children dress because they respected children's privacy. Fathers who work outside the city, give full child care to the mother and when they return home they always take the time to care for the children, starting from helping the children to bathe and clean themselves, helping to dress, eat and drink, and take the children to school. In addition, some fathers who are out of town take the time to make video calls with their children. The other father did not make video calls because he did not have sufficient facilities to do so. The aspects of accessibility and availability are important roles in the involvement of fathers in parenting. Accessibility is a form of the quality of the father is spending time with children in carrying out daily activities. Availability is a form of fabric of warmth, emotion, sensitivity, sensitivity, and children's participation.

The findings obtained in this study were as many as $37(55.2 \%)$ children with mental retardation according to their father were in the independent category with mild mental retardation and moderate mental retardation. This is under Sularyo \& Kadim (2017), which states that children with mild and moderate mental retardation can be educated and trained. This theory is supported by research by Muliana (2013), which states that as many as $16(53.3 \%)$ of 30 respondents with the category of moderate mental retardation have an independent level of independence. Sari \& Winata's research (2018), also states that $23(43.4 \%)$ children with mental retardation are independent in carrying out daily activities. The independence of daily activities for mentally retarded children includes toileting, cleaning, dressing, eating and drinking, and moving places. These skills cannot be separated from the involvement of fathers and nurturing, educating, and teaching children how to carry out daily activities. Performing daily activities can be realized optimally with the help of cultivating a healthy lifestyle from the people around them, including fathers, mothers, teachers, and the community.

The results of this study also showed that as many as 34 (50.7\%) respondents were able to move independently. As many as 7 respondents (100\%) were declared independent in moving places according to (Indardi, 2015). Another 
study stated that as many as 25 respondents $(50 \%)$ were declared independent in carrying out self-care activities (Septianti et al., 2016). Arfandi et al., (2014), found 29 respondents (56.9\%) in the quite independent category and 18 respondents $(35.3 \%)$ in the independent category. This study also produced data that as many as 34 (50.7) children were able to clean themselves independently. The results of research from Maidartati \& Aminah (2019), state that $60 \%$ of respondents are independent in self-care. This study also shows that as many as $39(58.2 \%)$ respondents are independent in eating and drinking. Supported by research by Tri et al., (2018), which shows that as many as 8 children with mental retardation can carry out daily activities such as eating and drinking independently. The inability to coordinate movements is one of the obstacles for children with mental retardation in moving places. In addition, age is also a factor in the independence of children with mental retardation. The more mature the child is, the more independent the child is from the learning process in his environment.

Some of the factors that influence the involvement of fathers in childcare are motivation, ability and selfconfidence, social support and stress, and factors of father's job (Day \& Lamb, 2004). Motivation and work factors are tied to the time fathers spend with their children. The higher the motivation of the father to be involved in caring for the father, the more time he will spend with the child. Meanwhile, the higher the father's working hours, the less time the father spends being involved in childcare. The social support given by mothers to fathers can increase the father's confidence in the father's ability to raise children. Lack of mother's support and trust can reduce the level of father's selfconfidence and decrease fathers' interest in caring for children.

The father's motivation can be influenced by factors from himself as well as factors from outside. Several factors from oneself that influence the father's motivation are a sense of responsibility for childcare to instill values and norms of life in the right society. Fathers with sons are more likely to be involved in parenting. External factors that affect the father's motivation are the embarrassment he gets from neighbors and parents, thus encouraging fathers to be involved in childcare. Strengthening inner motivation can maintain the stability of the father in maintaining his motivation to raise children.

In addition, the involvement of fathers in parenting is also influenced by the trust that mothers place in fathers in caring for their children. Fathers who earn this trust will not hesitate or fear wrongly in parenting their children. In addition, the trust given by the mother can also provide motivation and commitment for the father to continue to be involved in raising children. Mothers who hesitate in giving trust will make fathers hesitate and afraid in parenting their children. Thus reducing self-confidence and wanting to be involved in parenting can reduce the bonding between father and child.

\section{CONCLUSION}

This study concludes that the involvement of fathers in parenting with the level of independence of daily living activities in children with mental retardation in SLB-C TPA Jember is influenced by the father's motivation and the trust given by the mother to the father in caring for his child. The limitation of this study is that some respondents did not answer the questions according to the real situation. Things that the next researcher can do is conduct research using a qualitative method so that the researcher can find out the situation and condition felt by the father so that it can expand the scope of the research.

\section{REFERENCES}

Astrella, N. B. (2018). Jurnal Psikologi Retardasi Mental Yang Berada Dalam Kategori Berat ( Severe Mr ). Pada Umumnya Mereka Yang Berada Pada Kategori Ini, Mengalami Kesulitan Dalam Ketrampilan Berkomunikasi . Pada Usia Sekolah Dasar, Mereka Dapat Dilatih Untuk Ketrampilan Bi. 5(1), 38-49.

Abidin, R. (2017). Pedagogi: Jurnal Anak Usia Dini Dan Pendidikan Anak Usia Dini. Pedagogi, 3(3a), 72-77.

Arfandi, Z., Susilo, E., \& Widodo, G. G. (2014). Hubungan Antara Dukungan Sosial Keluarga Dengan Kemampuan Perawatan Diri Pada Anak Retardasi Mental Di SLB Negeri Ungaran. Jurnal Mahasiswa Program Studi Ilmu Keperawatan Stikes Ngudi, 26, $1-6$.

Https:/Www.Academia.Edu/34896980/Hubungan_Antara_Dukungan_Sosial_Keluarga_Dengan_Kemampuan_Perawatan_ Diri_Pada_Anak_Retardasi_Mental_Di_SLB_Negeri_Ungaran

Astrella, N. B. (2018). Jurnal Psikologi Retardasi Mental Yang Berada Dalam Kategori Berat ( Severe Mr ). Pada Umumnya Mereka Yang Berada Pada Kategori Ini, Mengalami Kesulitan Dalam Ketrampilan Berkomunikasi . Pada Usia Sekolah Dasar, Mereka Dapat Dilatih Untuk Ketrampilan Bi. 5(1), 38-49.

Asy, H., \& Ariyanto, A. (2019). Gambaran Keterlibatan Ayah Dalam Pengasuhan Anak (Paternal Involvement) Di Jabodetabek. Intuisi : Jurnal Psikologi IImiah, 11(1), 37-44.

Day, R. D., \& Lamb, M. E. (2004). Conceptualizing And Measuring Father Involvement. Lawrence Erlbaum Associates. 
Dewi Yustika Tri, Y., Apsari Nurliana Cipta, N., Wibhawa Budhi, B., \& Humaedi Sahadi, S. (2018). Activity Daily Living (Adl) Of Young People With Intellectual Disabilities. 153(Icddims 2017), 40-43. Https://Doi.Org/10.2991//cddims-17.2018.9

Haque, E. A., \& Rahmasari, D. (2013). Hubungan Antara Keterlibatan Ayah Dalam Pengasuhan Dan Kecerdasan Emosional Dengan Prilaku Prososial Pada Remaja [Correlation Between Father's Involvement In Parenting And Emotional Quotient Towards Pro-Social Behavior In Teenagers]. Character: Jurnal Penelitian Psikologi, 2(1), 1-9. Http://Ejournal.Unesa.Ac.Id/Index.Php/Character/Article/View/7114

Hardiyanti, A. (2018). Hubungan Gaya Asuh Orangtua Dengan Tingkat Kemandirian Activity Daily Living Pada Anak Disabilitas Intelektual Di SLB-C Tpa Kabupaten Jember. Skripsi.

Ikawati, Y., Dewi, Y. L. R., \& Adriani, R. B. (2017). Biopsychosocial Factors Associated With Mental Retardation In Children Aged 617 Years In Tulungagung District, East Java. Biological, Physical, Social, And Environmental Factors Associated With Dengue Hemorrhagic Fever In Nganjuk, East Java, 02(02), 119-129. Https://Doi.Org/10.26911/Jepublichealth.2017.02.02.03

Indardi, N. (2015). Pengulangan Teknik Permainan Kasti Terhadap Peningkatan Kemampuan Motorik Kasar Anak Tunagrahita Ringan. Journal Of Physical Education Health And Sport, 2(1), 44-49. Https://Doi.Org/10.15294/Jpehs.V2i1.3942

Khoiriyyah, A. (2020). A. Efektivitas Pelatihan Keterampilan Pengasuhan Untuk Menurunkan Stres Pengasuhan Pada Ibu Yang Memiliki Anak Retardasi Mental. Psikovidya, 24(1), 69-79. Https://Doi.Org/10.37303/Psikovidya.V24i1.152

Kleefman M, Jansen D, Stewart R, \& Reijneved S. (2014) The Effectiveness Of Stepping Stones Triple P Parenting Support In Parents Of Children With Borderline To Mild Intellectual Disability And Psychosocial Problems: A Randomized Controlled Trial. Universitas Gronginen. Bmc Medicine: Inggris. Lumbantobing,

Kosasih, H. (2018). Gambaran Penerimaan Orang Tua Dengan Anak Retardasi Mental Di Sekolah Luar Biasa (SLB) C "Dg" Dan SLB C "Sj." Psibernetika, 9(1), 27-36. Https://Doi.Org/10.30813/Psibernetika.V9i1.475

Lestari, S. 2012. Psikologi Keluarga: Penanaman Nilai Dan Penanganan Konflik Dalam Keluarga. Kompas Gramedia, Jakarta.

Maidartati, M. A., \& Aminah, E. S. (2019). Hubungan Dukungan Keluarga Dengan Kemandirian Perawatan Diri Anak Retardasi Mental Ringan-Sedang Di SLB Cicalengka. In Jurnal Keperawatan Galuh (Vol. 1, Issue 2). Https://Doi.Org/10.25157/Jkg.V1i2.2633

Muliana. (2013). Hubungan Dukungan Keluarga Terhadap Kemandirian Anak Retardasi Mental Sedang Di SLB Negeri Tingkat Pembina Provinsi Sulawesi Selatan Makassar.

Nikmatunasikah, K. (2018). Pshychological Well-Being Dan Keterlibatan Orang Tua Yang Memiliki Anak Berkebutuhan Khusus. In Universitas Muhammadiyah Malang.

Pravitasari, A. P., Nahariani, P., \& Huda, H. M. (2002). Retardasi Mental Di SLB Kurnia Asih Desa Pandean Kecamatan Ngoro Kabupaten Jombang ( The Description Of Mother's Role In Child Care Suffering Mental Retardation In SLB Kurnia Asih Pandean Ngoro Jombang ) Program Studi D3 Keperawatan Stikes Pemkab Jomban.

Rismhandani, F. N. (2018). Hubungan Antara Dukungan Istri Dengan Keterlibatan Ayah Dalam Pengasuhan Anak Berkebutuhan Khusus. In Universitas Islam Indinesia (Vol. 2).

Rohmalina, R., Lestari, R. H., \& Alam, S. K. (2019). Analisis Keterlibatan Ayah Dalam Mengembangkan Perkembangan Sosial Emosional Anak Usia Dini. Golden Age: Jurnal Pendidikan Anak Usia Dini, 3(1), 1-8. Https://Doi.Org/10.29313/Ga.V3i1.4809

Rumaseb, E., Mulyani, S., \& Nasrah. (2018). Hubungan Pola Asuh Orang Tua Dengan Tingkat Kemandirian Anak Retardasi Mental Usia 10-14 Tahun Dalam Melakukan Perawatan Diri Di SLB Negeri Bagian B Jayapura Ester. Jurnal Keperawatan Tropis Papua, 01(September), 1-7.

Sari, N. A. M. E., \& Winata, I. N. A. (2018). Faktor - Faktor Yang Mempengaruhi Kemandirian Anak Retardasi Mental Sedang Di Sdlb 1 Negeri Denpasar. Bali Medika Jurnal, 5(2), 126-133. Https://Doi.Org/10.36376/Bmj.V5i2.42

Sari, O. A., \& Santy, W. H. (2016). Hubungan Dukungan Keluarga Dengan Tingkat Kemandirian Personal Hygiene Anak Tunagrahita Di SLB Tunas Mulya Kelurahan Sememi Kecamatan Benowo. Jurnal Ilmiah Kesehatan, 10(2), 164-171.

Sartika. (2017). Hubungan Peran Orangtua Dengan Tingkat Kemandirian Activity Daily Living (Adl) Pada Anak Dengan Retardasi Mental Di Kabupaten Sleman. Skripsi.

Septianti, A., Rokayah, C., \& Mustofa, A. (2016). Abstract. Jurnal limiah Permas: Jurnal IImiah Stikes Kendal, 6(2), 58-64.

Situmeang, J. P. S., Bidjuni, H., \& Lolong, J. (2016). Hubungan Status Sosio Demografi Dan Status Akademik Anak Dengan Kemandirian Anak Retardasi Mental Di SLB Yayasan Pembinaan Anak Cacat Manado. E-Journal Keperawatan (E-Kp), 4, 17.

Sularyo, T. S., \& Kadim, M. (2017). Retardasi Mental. Sari Pediatri, 2(3), 170.Https://Doi.Org/10.14238/Sp2.3.2000.170-7

Supartini, Yupi. 2004. Buku Ajar Konsep Dasar Keperawatan Anak. Jakarta: Egc.

Syahda, S. (2018). Hubungan Dukungan Keluarga Terhadap Kemandirian Anak Retardasi Mental Di Sdlb Bangkinang Tahun 2016. Jurnal Basicedu, 2(1), 43-48. Https://Doi.Org/10.31004/Basicedu.V2i1.25

Wangge, F. K. M., Thoomaszen, F. W., Bunga, B. N. K., And Kiling, I. Y. 2016. Identifikasi Afeksi Paternal Pada Ayah Dari Anak Usia Dini Di Kota Kupang. Jurnal IImiah Visi Pptk Paudni, 11(1): 41- 48.52

Zubaidah Ummi. (2014). Hubungan Pola Asuh Orang Tua Dengan Tingkat Kemandirian Personal Hygiene Pada Anak Retardasi Mental Di SLB Negeri 2 Yogyakarta. Naskah Publikasi, 561-565. 